Nadwa : Jurnal Pendidikan Islam

Vol. 12, Nomor 2 Tahun 2018

Accredited by Ristekdikti based on Decree No. 51/E/KPT/2017

\title{
Islamic Education in Supporting De-radicalization: A Review of Islamic Education in Pondok Pesantren
}

\author{
Tiyas Nur Haryani, \\ tiyasnurharyani@staff.uns.ac.id, \\ Muhammad Ikhsanul Amin, \\ muhikhsan45@student.uns.ac.id \\ Nur Hidayatul Arifah, \\ nurhidayatularifah1996@gmail.com,
}

\section{Arina Mardhiyana Husna}

arinahusna43@gmail.com

Sebelas Maret University

\begin{abstract}
This article present of the result of research about pondok pesantren (Islamic religious boarding school) education in confronting radicalism, focusing in researching the efforts of Pondok Pesantren Darusy Syuhadah in confronting radicalism. Collecting qualitative data through observation, documentation, and purposively sampled interviews. The result shows that pesantrens have a significant role in overcoming radicalism through its management of education model and curricula. Pondok Pesantren Darusy Syuhadah with Salaf education model build teaching and education to create generation of $d a^{\prime} i$ (Islamic missionaries) and teachers of Islamic religion, so the curriculum prioritizes politeness and away from radicalism.
\end{abstract}

Keywords: Indonesia, education, pesantren, radicalism

\begin{abstract}
Abstrak
Artikel ini mempresentasikan hasil penelitian tentang pendidikan pondok pesantren dalam menghadapi radikalisme, memfokuskan pada upaya yang dilakukan pesantren Salaf di Pondok Pesantren Darusy Syuhadah dalam menghadapi radikalisme. Data kualitatif dikumpulkan melalui observasi, dokumentasi, dan wawancara purposive sampeling. Hasilnya menunjukkan bahwa pesantren memiliki peran yang signifikan dalam mengatasi radikalisme melalui pengelolaan model pendidikan dan kurikulumnya. Pondok Pesantren Darusy Syuhadah dengan model pendidikan Salaf membangun pengajaran dan pendidikan untuk menciptakan generasi da'i dan guru agama Islam, sehingga kurikulumnya mengutamakan kesantunan dan jauh dari radikalisme.
\end{abstract}

Kata kunci: Indonesia, pendidikan, pesantren, radikalisme

IS SN 1979-1739 (P) ; ISSN 2502-8057 (E).

C) 2018 Nadwa : Jurnal Pendidikan Islam / UIN Walisongo.

Accredited by Ristekdikti based on Decree Na 51/E/KPT/2017

http://jounal.walisongo.ac.id/index.php/nadwa 


\section{Introduction}

Globalization makes information, culture, and ideology penetrate a country easily. One of the ideologies rapidly expanding within the stream of globalization is radicalism. Radicalism as an ideology, having a feature of being revolutionary, in which it tries to change status quo, turns into phenomenon drawing international attention, especially when the groups affiliated with this ideology use religious symbols and instrument of violence in actualizing their concept. Radicalism is familiarly understood as a part of Islamic left extremists' revolution.1 This ideology is more amplified after infiltrating within the stream of globalization distributed beyond geographical boundaries of countries. This has implications to a more expanding spectrum of radicalism, presently ranging from macro (global) to micro (local) environment.

As a country with the largest Muslim population, Indonesia becomes a kind of magnet of interest for the adherers of radical ideology who can disunite the country. Bombings which happened in the last two decades, such as Bali bombings, Marriot hotel bombings, Thamrin Avenue bombings, to the recent bombings of Surabaya churches, has given a strong legitimacy to the existence of radical movement in the country, which in this incident placed themselves into the highest frequency for conducting terror. Radicalism thrived and started to appear in the surface post-Reformation era, after the downfall of Suharto in 1998. In essence, the ideology of radicalism has grown in Indonesia within underground movements. The ideology was much brought from Middle Eastern countries, which are extremist in nature. Recent trends presented by Wahid Foundation with Lingkar Survei Indonesia (Indonesia Survey Circle) shows that in 2016, a total of 11 million from 150 million of Indonesian Muslim population were ready to conduct radical acts. The number is equivalent to 7.7 percent of the total Indonesian Muslims. It also mentioned that 600 thousand or 0.4

\footnotetext{
1 Ma'arif, Syamsul. 2014. Ideologi Pesantren Salaf : Deradikalisasi Agama dan Budaya Damai. Ibda' Jurnal Kebudayaan Islam, Vol.12, No, 2, Juli Desember 2014.
} 
percent of Indonesian Muslims have ever done a form of radical act. (http://wahidfoundation.org, 2016).2 It is by that reason that radicalism becomes a latent danger which should be put under cautious scrutiny, since it threatens Indonesia's existence.

Through those approaches, experts have tried to identify the factors causing an individual to be radical. They saw that these factors are multidimensional in nature and inter-correlating. This research's novelty is that it tries to give attention to the Islamic education in the effort of de-radicalization, reviewed from pesantren experiences.

Social, economic, environmental, educational, and political factors play a significant role in influencing Islamic radicalism. However, Islamic radicalism is usually driven by the narrow understanding of religion, feelings of oppression and subjugation, psychosocially unsafe condition, and local or global injustice. 3 Religious radicalism movement can also be seen as a reassertion of religious identity for all faithful in the entire world as a dialectical consequence to the waves of modernism, secularism, and globalism perceived to destroy the barriers of locality and tradition of a nation. 4 This reassertion is more strengthened after globalization is perceived as the disease causing decadence and alienation of religious values, both locally and globally.

A good educational system is a solution effort in preventing the expansion of radicalism. Education becomes one of the fields bearing the role in prevention and countering the expansion of radicalism in the society in general and nuclear family level in a more narrow sense. One of the educational institutions in Indonesia which falls under a careful scrutiny since it is perceived to be able to prevent radicalism is

2 Wahid Foundation. 2016. RI Masih Rentan Intoleransi, Wahid Foundation Sampaikan Enam Rekomendasi. Wahid Foundation. $\leq \mathrm{http}: / /$ wahidfoundation.or/index.php/news/detail/RI-Masih-Rentan-Intoleransi-

Wahid-Foundation-Sampaikan-Enam-Rekomendasi>. 9 Oktober 2017 (20.15)

3 Abdullah, Amin M. 2005. Pendidikan Agama Era MultikulturalMultireligius. PSAP. Jakarta.

4 Hasan, Noorhaidi. 2008. Laskar Jihad: Islam, Militansi, dan Pencarian Identitas di Indonesia Pasca Orde Baru. LP3ES-KITLV. Jakarta. 
pesantren. Pesantren is defined as an Islamic educational institution growing and acknowledged by local population, using dormitory (campus) system, with its system of education or madrasa is under the leadership of one or more charismatic Kyais, attributed by their independence in all walks of life (Arifin 1995: 240). 5

Results of sociological-anthropological study by Zamakhsyari Dhofier revealed that pesantren as an alternative educational institution, since its conception to approaching 1970 s, is a unique educational institution, including the community within its walls comprising the kyai, the santris (students of pesantren), the mosque, and the kitab kuning (traditional set of Islamic texts used by the Islamic educational curriculum in Indonesia) $)^{4}$. In this phase, pesantren is more a cultural movement distanced from Islamist political movement in the country. ${ }^{4}$ Pesantren is responsible to create ulemas with broad knowledge (tafaqquh fi al-din).6 Hence, pesantren teaches all things in the religion, ranging from tawhid and sharia, to akhlaq. The pesantren's authenticity since conception enables them to present a friendly and peaceful image. In remote areas of Sumatra to Papua, especially Java, both salaf (traditional) and khalaf (modern) pesantrens are able to connect with the local culture. The inclusive nature of pesantren is not only able to show an accommodating attitude toward local culture, but also become a role model of attitudes of tolerance and plurality of Muslims in general. It is unsurprising that consequently, Indonesian Muslims are viewed as friendly and peaceful. Abdurrahman Wahid even expressly named pesantren as a subculture incarnating into one of the pillars of Indonesian cultural identity with all of its plurality.7

Pesantren has consistently evolved along with changing times. This has implications to the teaching pattern and the

5 Dhofier, Zamakhsyari. 1994. Tradisi Pesantren Studi Tentang Pandangan Hidup Kyai. LP3ES. Jakarta.

6 Wahid, Marzuki, dkk. 1999. Pesantren Masa Depan. Pustaka Hidayah. Bandung.

7 Wahid, Abdurrahman. 2001. Menggerakkan Tradisi: Esai-Esai Pesantren. LKIS. Yogyakarta. 
disparity of ideological basis. Since Reformation, pesantren has experienced turbulent dynamics and fast changes, especially when intersecting with Islamic ideological dimension, either in national or transnational scale. At this phase, pesantren then produces various unthinkable meanings, functions, and images, since in this era, all things can be raised legally in the name of freedom and democracy, including the conception of pesantren with transnational ideology.8 Quoted from CNN Indonesia website, the Head of National Counter-Terrorism Agency, Saut Usman Nasution said that there are 19 (pesantren) which can be categorically included as being involved with radical movement, which is followed by the lecturers, teachers, or santris.9

However, the existence of pesantren can also be a gap enabling the growth and expansion of radical ideology when the teachings and education conducted deviate from national goal and cannot be accounted for. Pesantren becomes a body which is able to actively countering radicalism, but also can become the hotbed of radicalism itself. The fact shows that it is important to give attention to the pesantren education model in Indonesia. Pesantren is like two sides of a coin; on one side, pesantren is perceived to be able to combat radicalism through its education model and policy, on the other side, pesantren is considered susceptible to the spread of radicalism through its international networks which may be infiltrated by radical movement and also able to build networks of radical movement in the country. Lasmana revealed that in its development, pesantren is often connected to the fundamentalist radical movement, but pesantren also has a significant role in building

8 Fox, Richard. 2006. Strong and weak media? On the Representation of Terorisme in Contemporary Indonesia. Journal of Modern Asian Studies. Cambridge University Press 4(40) : 993-1052.

9 Armenia, Resty. 2016. BNPT : 19 Pesantren Terindikasi Ajarkan Radikalisme. $\mathrm{CNN}$ Indonesia.

<https://www.cnnindonesia.com/nasional/20160203201841-20108711/bnpt-19-pesantren-terindikasi-ajarkan-radikalisme/>. 11 Oktober 2017 (12.58). 
pluralism.10

Observing the background of radicalism and pesantren education, it becomes interesting to conduct basic research about pesantren education model in confronting radicalism. On the outline, studies about radicalism give much attention to the process of radicalization and the impacts of radicalism.11 12 This research was conducted in pesantren in Surakarta ex-Residence, and in particular explored the education model of Pondok Pesantren Darusy Syahadah in Boyolali, Central Java, which implements salaf pesantren education model. The pesantren itself is considered to have a diversity of pluralism among its teachers and santris. The expanding radical movement in Indonesia can threaten the country's unity. The research result is also important to support references in identifying pesantren education model to confront global radicalism.

\section{Background of radical movement}

It is usually stated that the escalation of radical movement happening on Islam has roots on the gap between theoretical and practical view of Islamic teachings crashing with each other in the field of interpretation of Quran and Sunna. In theory, the idealization of ideas seems to be very impressive and universal, but in practice there are various expressive forms that are difficult to implement. The difficulty usually emerges because of haste interpretation of meaning, or too utopist interpretation in the practical world. Quoted by Alwi Shihab, Ibnu Arabi (1165-1240) said that the difference in human ability in understanding Quran causes each text to have seven different levels of understanding. The level of understanding owned by the Angel Jibril who firstly received revelation from Allah, would certainly be different compared to those owned by the

10 Lasmana, Nunung. 2017. Deradikalisasi Agama Melalui Pesantren. Tajdid: Jurnal Pemikiran Keislaman dan Kemanusiaan Vol 1 No 1April 2017.

11 Malik, Abdul, Dkk. 2016. Kultur Pendidikan Pesantren Dan Radikalisme. Jurnal Pembangunan Pendidikan: Fondasi dan Aplikasi Volume 4, No 2, Desember 2016 (103-114).

12 Nurrohman. 2010. Jihad dan Radikalisme dalam Perspektif Pesantren di Jawa Barat. Jurnal Penelitian Keislaman Vol. 06 No.2 Juni 2010: 339-360 
Prophet Muhammad when he received it through Jibril. Then, the level of understanding from the Prophet's sahabah would certainly be different compared to the next generation of Muslims in history, and so on, according to Ibnu Arabi.13 This gave a space to the human's effort of interpretation in solving contemporary problems which do not have explicit arguments in the Quran or Sunna, with explicit note of not straying from Islamic principles. The interpretations were conducted to find a common ground between Islamic essence and the spirit of everchanging times.

Interpretation of the Quran and the Prophet's Sunna in a textual way present rules through processes not involving intellectual dialectics, which gives much attention to the texts' historicity, such as social reality, community law anthropology, object, or moral ideals when the religious texts are inspired. This causes expression to emerge as a response to messages by Muhammad and the meaning of Islam which comes from literal, as-it-say interpretation, as assuming that all the messages in the Quran and Sunna can be directly implemented. Things intrinsically which are found in the textual appearance experience alienation which does not exclude the possibility of creating negation to these intrinsic things. Those who believe in literal approach to interpretation reject critical study to the religious texts, like hermeneutics, a study coming from language philosophy tradition assuming that the Quran and Hadith should be understood, interpreted, translated, and put into dialogue in order to interpret recent social reality. 14 Calls to kaffah form of Islam are just simplified as an order to revert to the period of early Islamic conception. This belief is actually a form of obsession to the romanticism of Islam in Muhammad era absolutely actualized without respecting the socio-cultural transformation the society experiences, so that in the process it appears to be forced by taking a puritan image in seeking its authenticity. This form of interpretation in turn will create an

13 Shihab, Alwi. 1999. Islam Inklusif, Menuju Sikap Terbuka dalam Beragama. Cetakan kelima. Mizan. Bandung.

14 Hidayat, Komaruddin. 1996. Memahami Bahasa Agama: Sebuah Kajian Hermeneutik. Paramadina. Jakarta. 
exclusive attitude to the truth from other ideologies. This kind of exclusive attitude will enslave thoughts of Muslims, that it will cause antipathy toward ideologies different from their own interpretation, which in turn will conceive violent acts and terror. Textual-literal and rigid tactics of religious text interpretation had contributed to the expansion of social conflict initiated by violence in religion. There are not a few texts from the Quran and Hadith vulnerable to the wrong use of interpretation, like those concerning jihad, takfiri (infidelization), tasyriki (judgment of those practicing idolatry), to shahidism. These verses if interpreted wrongly will cause some thoughts putting those verses as the central theme related to Muslims' view toward differing communities and religions. At its highest frequency, the social facts of individuals or groups espousing textual interpretation will be sectarian and not tolerating negotiation or consensus. The seeds of growth of religious violence are the literal-scriptural understanding of religion and its derivation of exclusive and apologetic social attitude. 15

In addition to scriptural interpretation which at certain frequency bears fruit to fundamentalist mindset, there is also liberal interpretation participating in degrading the roots of radicalism. However this liberalistic approach appears as a clandestine, or indirect religious radicalism roots. Liberal interpretation dares to go out from the textual bondage on interpretation, but then strayed, alienating verses of Quran and Sunna. Presentation of religious regulations is formed through a process putting the texts' historicity as a consideration, but in the dialectical process does not consider the literal textual devices. The texts are too laxly interpreted so that the meaning gained clashes with the texts itself, including muhkamât verses from the Quran. Such form of understanding traps this group into stressing too much freedom in the role of reason, so that they clash main principles of Islam. Therefore, the output of this kind of interpretation raises many dubious statements, such as

15 J. Adams, Charles. 1976. Islamic Religion Tradition, dalam Leonard Binder, The Study of the Middle East: Research and Scholarship in the Humanities and the Social Sciences. John Wiley and Sons. New York. 
assuming all religions are the same, and de-existing Muhammad SAW as a mere human. This kind of statement directly contravenes the statement by Allah that it is only Islam being the religion He shows favor, and His affirmation that the Prophet Muhammad SAW is the last prophet of all prophets. It is these kinds of understanding that becomes a stimulus and legitimacy to the scripturalist-literal and fundamentalist groups to amplify their teachings with calls to revert to kaffah Islam, but in a simplified form.

\section{Pondok Pesantren Darusy Syuhadah}

Pondok Pesantren Darusy Syuhadah is a salaf model pesantren located in Boyolali, Jawa Tengah, Indonesia. The pesantren is located in village area and has 8 ha area for male boarding and 1.2 ha area for female boarding in a separate land. It is in the middle of villagers' settlements, with the homes of administrators, ustaz (male preachers), and ustazah (female preachers) of the pesantren surrounding it. There are some supporting facilities within the pesantren, such as mosque, classrooms, health post, co-ops, libraries, dormitories for santris, guest rooms for visiting santris' families, and outsideclass environment for the santris.

Pondok Pesantren Darusy Syuhadah has grown rapidly until present day. Interviews with Ustaz Qosdi Ridwanullah, Mudzir (head administrator) of PP. Darusy Syahadah, revealed that the pesantren had 25 total santris during its conception. In 1999, the number grew more than 100 santris. In 2018, the pesantren took care of 650 male santris and 500 female santris coming from various regions, such as Surakarta ex-Residency, and outer-Java regions, notably Aceh and Papua. The diverse socio-cultural background is apparent in the pesantren if looked from the santris' hometown.

The pesantren's education model is developed integrally with a curriculum combined from classical-formal and salaf curricula. As an Islamic educational institution, Pondok Pesantren Darusy Syuhadah aims to prepare prospective da'is (Islamic missionaries) who engaging in Islamic $d a$ 'wah (preaching). The education systems implemented in the 
pesantren are classical, sorogan or studying Turats books (kitab kuning), santri development by akhlaq (character) building, worship, and ruqya (exorcism), and also the preaching practices to the santris. Pondok Pesantren Darusy Syuhadah has daily, weekly, monthly, and semester activities. The documentation conducted through the pesantren's official website, together with observation data gathered, shows that there are daily activities in the mosque as the way of gathering of santris and routine Islamic worship activities like salat, tilawah (recitation of the Quran), and studying Arabic language. The weekly activities conducted are muhadharoh (speech) by santris in Indonesian, Arabic, and English. Others include public preaching in the community, public work in pesantren's surroundings, and extracurricular activities of martial arts and hiking. The pesantren's monthly activity is tausyiah from ustaz outside the pesantren and in-depth book discussion. Class meeting becomes the semester activities. Pondok Pesantren Darusy Syuhadah has a program of education for students passing their Junior High School education, in form of a threeyear course of SeniorSecondary School, Quran memorizing, and Arabic language.

The pesantren had ever been a source of talks because of its alleged involvement in Jakarta terrorism acts of 2016. However, Ustaz Qosdi Ridwanullah, Mudzir (head administrator) PP. Darusy Syahadah stated that the pesantren alumni involvement in Indonesian terror acts was mainly caused by the external environment after santris had finished their education. For the most part, Pondok Pesantren Darusy Syahadah cannot be categorized into entering networks espousing radical ideology. The pesantren is an Islamic educational institution whose main objective is Islamic brotherhood engaging in education to build an Islamic generation upholding Islamic religion.

\section{Islamic teaching in pesantren in relation to confronting radicalism}

The description above shows the importance of Islamic education, especially in pesantren to prevent the growth of radicalism. The research conducted at Pondok Pesantren Darusy 
Syahadah shows that the pesantren uses mixed model of education, between Salaf and modern. The first model developed in this institution is based more on the Salaf education model. It is visible from the observation and interviews with the mudzir that the curricula was developed internally by the administrators of Yasmin foundation, the parent body of Pondok Pesantren Darusy Syahadah together with the ustaz and ustaza of the pesantren. The curricula developed tend to be exclusive in nature, since they are organized, supervised, and evaluated only by the pesantren internal parties. Basically, the things done by the pesantren are the characteristics of local education system, which is the reality for most Salaf education model appliers. It is because of that that the research found that Pondok Pesantren Darusy Syahadah is a pesantren with predominantly Salaf education model applying local education system.

Other findings revealed the fact that Pondok Pesantren Darusy Syahadah in its curricula studies translated Salaf books, written by Salaf ulemas, such as interpretation by Ibn Katsir, a series of Quran interpretation by Ibn Katsir. Previous research conducted by Khotib showed that the Ibn Katsir interpretation is an example of classic model of interpretation which obtained the meaning in a literal-textual way16 In making the curricula, the pesantren only involve their internal parties. This has an implication to textual Quran interpretation.

Pondok Pesantren Darusy Syahadah has inserted course materials about national awareness and nationalism in dauroh activity, a training or teaching activity inside the pesantren. However, the course materials are still minimally given to the santris in dauroh activity. According to the administrators, the national awareness is perceived to be clandestinely contained in religious texts, both in the Quran or Sunna. Pesantren tends to give additional space for its santris to independently identify the concept of national awareness without being tied up to a rigid structure set by the pesantren. This results into a contrast of

16 Khotib, Baijuri A. 2016. Corak Penafsiran Al-Qur'an (Periode KlasikModern). Jurnal Hikamuna Edisi 1 Vol.1 No.1 Tahun 2016. 
understanding between respective santris about the concept of national awareness because of the difference in perspective and interpretation of each individual which does not rule out the possibility towards a rigid textual interpretation.

The other result of the research shows that the role of Islamic education in pesantren in combating radicalism become not maximized when a pesantren is exclusive, and has a great potential of leaning towards radicalism when using textual approach of interpretation. Pesantren needs to involve external parties in its development, not only in financial aspects. Islamic education can provide a countermeasure to radicalism and preserve the country's stability, by inserting or giving curricula of nationalism and national awareness, and the involvement of external stakeholders in pesantren's development.

\section{Conclusion}

Conclusion taken from the research result indicates that the Salaf education system in localized pondok pesantren is susceptible to the textual interpretation model. Such pesantren education pattern can be a counter-radicalism one if it is inclusive in its curriculum organization, by involving parties outside the pesantren. Course materials, particularly about national awareness and nationalism, should be inserted into the curriculum as an effort to immunize santris to radicalism.

The research is, therefore, able to suggest that the moderate approach to interpretation of religious texts emerges as a reaction to both rigid approach and the approach allowing for too much freedom, in which this type of interpretation rigorously tries to understand substantial and essential meaning behind literal Quranic texts. The textual value of religious texts, especially muhkamât verses are acknowledged and made as the guidelines so that the interpretation does not come out of the core of Islamic teachings. The spirit of moderate interpretation carries the human freedom of thought in studying Quran and Hadith verses contextually, with the only condition of not to stray from Islamic primary values. Therefore, they are consolidate tawhid, and not fanaticism (textual) to understand Islamic teaching, and to adopt positive influences from Western 
thoughts. It means that moderate approach to interpretation lies between fundamentalist and liberalist approaches. Moderate approach believes the existence of dynamic and rational elements within religious texts, and thus presenting religious principles through intellectual dialectic process which considers the texts' historicity, but still paying attention to the their textual dimension, so that it will do no harm to the authenticity of the Quran and sunna. With its moderate-substantial model of educational approach, it still gives a considerable attention to the literal texts but also consider their substance and historicity. This thought blends formal-doctrinal formula with concern to socio-historical view of the text and the ever-evolving praxis in society. A moderate understanding of Islam can adapt well with the society's social, political, economic, and psychological environment in every generation without being detached from its principal teachings. The moderate model of religious education can bring up attitude of tolerance, non-judgmental, and compassion, which can erode and confront radical ideology. This understanding of Islam established as the standard curricula and absorbed by the student unit of pesantren.

\section{Acknowledgement}

The research team wants to offer their gratitude to the Ministry of Research, Technology, and Higher Education, which had provided Higher Education grants in the scheme of Students Creativity Program of 2017 in the research conducted.

\section{References}

Abdullah, Amin M. Pendidikan Agama Era MultikulturalMultireligius. PSAP. Jakarta, 2005.

Armenia, Resty. BNPT : 19 Pesantren Terindikasi Ajarkan Radikalisme. CNN Indonesia, 2016. <https://www.cnnindonesia.com/nasional/20160203201841-20108711/bnpt-19-pesantren-terindikasi-ajarkan-radikalisme/>. 11 Oktober 2017 (12.58).

Dhofier, Zamakhsyari. Tradisi Pesantren Studi Tentang Pandangan Hidup Kyai. LP3ES. Jakarta, 1994.

Fox, Richard. Strong and weak media? On the Representation of Terorisme in Contemporary Indonesia. Journal of Modern 
Asian Studies. Cambridge University Press 4(40) (2006): $993-$ 1052.

Hasan, Noorhaidi. Laskar Jihad: Islam, Militansi, dan Pencarian Identitas di Indonesia Pasca Orde Baru. LP3ES-KITLV. Jakarta, 2008.

Hidayat, Komaruddin.. Memahami Bahasa Agama: Sebuah Kajian Hermeneutik. Paramadina. Jakarta, 1996

J. Adams, Charles. Islamic Religion Tradition", dalam Leonard Binder, The Study of the Middle East: Research and Scholarship in the Humanities and the Social Sciences. John Wiley and Sons. New York, 1976.

Khotib, Baijuri A. Corak Penafsiran Al-Qur'an (Periode KlasikModern). Jurnal Hikamuna Edisi 1 Vol.1 No.1 Tahun (2016).

Lasmana, Nunung. Deradikalisasi Agama Melalui Pesantren. Tajdid: Jurnal Pemikiran Keislaman dan Kemanusiaan Vol 1 No 1April 2017.

Ma'arif, Syamsul, Ideologi Pesantren Salaf : Deradikalisasi Agama dan Budaya Damai. Ibda' Jurnal Kebudayaan Islam, Vol.12, No, 2, Juli - Desember 2014.

Malik, Abdul, Dkk. Kultur Pendidikan Pesantren Dan Radikalisme. Jurnal Pembangunan Pendidikan: Fondasi dan Aplikasi Volume 4, No 2, Desember 2016 (103-114).

Nurrohman. Jihad dan Radikalisme dalam Perspektif Pesantren di Jawa Barat. Jurnal Penelitian Keislaman Vol. 06 No.2 Juni 2010: 339-360.

Sarwono, Jonathan, Metode Penelitian Kuantitatif dan Kualitatif. Graha Ilmu. Yogyakarta, 2006.

Shihab, Alwi. 1999. Islam Inklusif, Menuju Sikap Terbuka dalam Beragama. Cetakan kelima. Mizan. Bandung.

Wahid, Marzuki, dkk. 1999. Pesantren Masa Depan. Pustaka Hidayah. Bandung.

Wahid, Abdurrahman, Menggerakkan Tradisi: Esai-Esai Pesantren. LKIS. Yogyakarta, 2001.

Wahid Foundation. RI Masih Rentan Intoleransi, Wahid Foundation Sampaikan Enam Rekomendasi. Wahid Foundation,2016. 〈http:// wahidfoundation.or/index.php/news/detail/RI-MasihRentan-Intoleransi-Wahid-Foundation-Sampaikan-EnamRekomendasi>. 9 Oktober 2017 (20.15) 